\title{
Malignant hypertension: new aspects of an old clinical entity
}

\author{
Andrzej Januszewicz ${ }^{1}$, Tomasz Guzik², Aleksander Prejbisz ${ }^{1}$, \\ Tomasz Mikołajczyk², Grzegorz Osmenda², Włodzimierz Januszewicz ${ }^{3}$ \\ 1 Department of Hypertension, Institute of Cardiology, Warsaw, Poland \\ 2 Department of Internal and Agricultural Medicine, Jagiellonian University Medical College, Kraków, Poland \\ 3 Warsaw, Poland
}

\section{KEY WORDS}

malignant

hypertension,

pathogenesis,

prevalence, treatment
Correspondence to:

Aleksander Prejbisz, MD, PhD,

Klinika Nadciśnienia Tętniczego

Instytut Kardiologii, ul. Alpejska

42, 04-628 Warszawa, Poland,

phone: +482234343 39,

e-mail: a.prejbisz@ikard.pl

Received: November 12, 2015.

Accepted: November 16, 2015

Published online:

December 10, 2015.

Conflict of interest: none declared.

Pol Arch Med Wewn. 2016;

126 (1-2): 86-93

Copyright by Medycyna Praktyczna,

Kraków 2016

\section{ABSTRACT}

Malignant hypertension (MHT), also known as accelerated-malignant hypertension or malignant-phase hypertension, is the most severe form of arterial hypertension. It is defined clinically as high blood pressure (BP) levels associated with lesions of the retinal fundus (flame-shaped hemorrhages, exudates, or cotton wool spots, with or without papilledema). Despite the availability of a vast range of antihypertensive agents, MHT continues to be a significant clinical challenge. Although its prevalence is very low, the absolute number of new cases has not changed over the past decades. While the role of the activation of the renin-angiotensin-aldosterone system and endothelial dysfunction in the pathogenesis of MHT has been well described, recent studies have indicated that the immune system may also play an important role in the development of this condition. Patients with MHT are characterized by pronounced target organ damage, including structural and functional cardiac abnormalities. MHT is frequently complicated by renal insufficiency and end-stage renal disease. The survival rates for patients with MHT have improved considerably with increased availability of antihypertensive treatment. However, renal insufficiency and end-stage renal disease still remain a significant cause of morbidity and mortality in this patient group. In conclusion, MHT is not a "vanishing disease" because there is a relatively stable number of new cases per year. Nonetheless, prognosis and survival rates in these patients have improved significantly owing to earlier detection, stricter BP control, lower BP targets, better choice of antihypertensive drugs, and availability of hemodialysis and renal transplantation.

Introduction Malignant hypertension (MHT), also known as accelerated-malignant hypertension or malignant-phase hypertension, is the most severe form of hypertension; it is defined clinically as high blood pressure (BP) associated with bilateral retinal flame-shaped hemorrhages, exudates, or cotton wool spots, with or without papilledema. In the 2010 revision of the Dutch guidelines for the management of hypertensive crisis, van den Born et $\mathrm{al}^{1}$ replaced the term "malignant hypertension" with "hypertensive crisis with retinopathy", which was followed by Kaplan and Victor in the 2015 edition of Kaplan's Clinical Hypertension. The authors concluded that the presence of retinopathy may allow other target organs to be included, making the description of this type of emergency more accurate..$^{1-3}$
MHT is associated with failure in BP autoregulation and develops when the mean arterial pressure (MAP) reaches a critical level of $150 \mathrm{mmHg}$, as reported in experimental animals. Fibrinoid necrosis appears in the arterial walls, which may be caused by vasoactive factor(s) or may be a nonspecific consequence of very high BP. ${ }^{1}$

In patients with $\mathrm{MHT}$, very high systolic $\mathrm{BP}$, and in particular significantly elevated diastolic $\mathrm{BP}$, are surrogate markers of increased peripheral vascular resistance associated with an increase in MAP, an abnormal nonpulsatile component of BP. ${ }^{4}$

Even though the introduction of modern multidrug antihypertensive therapy has resulted in better BP control and markedly improved prognosis, MHT is still a life-threating manifestation of hypertension and represents a clinical entity characterized by high cardiovascular risk and 
FIGURE 1 Postulated pathophysiological mechanisms of malignant hypertension

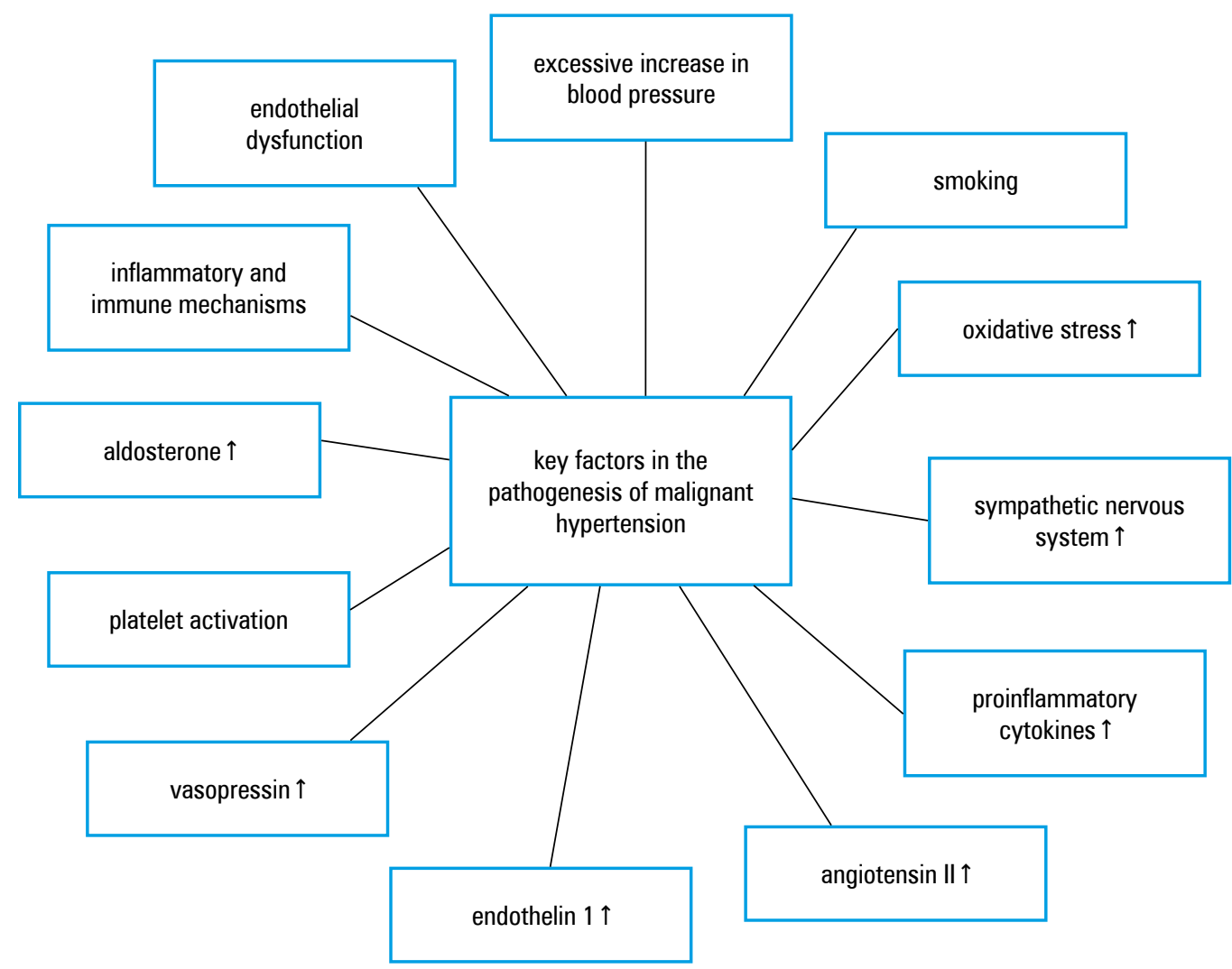

elevated risk of developing end-stage renal disease (ESRD) in a long-term follow-up.

Incidence of malignant hypertension Despite the vast range of antihypertensive agents and effective BP control, MHT remains an important clinical entity. Although its frequency is very low, the absolute number of new cases has not changed much over the past decades, as documented by recent studies.

The study by Lane et $\mathrm{al}^{5}$ examined the changing demography and survival of 446 patients with MHT attending the City Hospital in Birmingham, United Kingdom, from 1964 to 2006, with a median follow-up of 103.8 months. In this largest prospective analysis in the world literature, the number of new cases of MHT has not changed substantially over 40 years. The study supports the concept that MHT is not a vanishing disease, with a relatively stable number of 2 to 3 new cases of MHT per 100000 head of population per year. ${ }^{5}$ The demography of the disease has not altered during the follow-up, with no significant differences in the mean age at diagnosis, but with a slight predominance in men. It is of note that during the follow-up, there was a significant increase in the proportion of ethnic minorities, including South-Asians and Afro-Caribbeans, and a significant decrease in white Europeans. ${ }^{5}$ Another smaller study evaluating European cohorts demonstrated a fairly stable incidence of MHT, with 2 to 3 new cases per 100000 head of population over the past 30 years. ${ }^{6}$

A recent retrospective cohort study investigated national trends in the United States in hospital admissions for MHT, identifying all hospitalizations between 2000 and 2011 during which a primary diagnosis of MHT was recorded. ${ }^{7}$ The results clearly demonstrated a much higher rate of increase in the number of hospitalizations with a primary discharge diagnosis of MHT during this time period. The rate of annual hospitalizations for MHT remained stable before 2007, but then started to significantly increase at an esti-

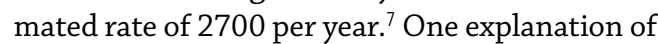
the results is that the reported data represented a true change in the epidemiology of hypertensive emergencies. Another cause of the change, which is much more likely, is that this abrupt increase resulted from a change in coding practices in the United States. ${ }^{7}$

Pathophysiological mechanisms Possible pathophysiological mechanisms for the development of MHT have been proposed, including rapidly increasing BP, pressure diuresis and natriuresis, severe renal vasoconstriction, and ischemia (FIGURE 1). In addition, activation of the renin-angiotensin-aldosterone system (FIGURE 2), microangiopathy, hemolytic anemia, and development of retinopathy are observed in MHT. The vascular lesions of MHT include myointimal proliferation and fibrinoid necrosis. ${ }^{8-21}$

The immune system in malignant hypertension While the role of endothelial dysfunction and kidney damage in MHT has been addressed by numerous other reviews, recent studies have indicated that the immune system, and in particular $\mathrm{T}$ cells, play a crucial role in the development of 


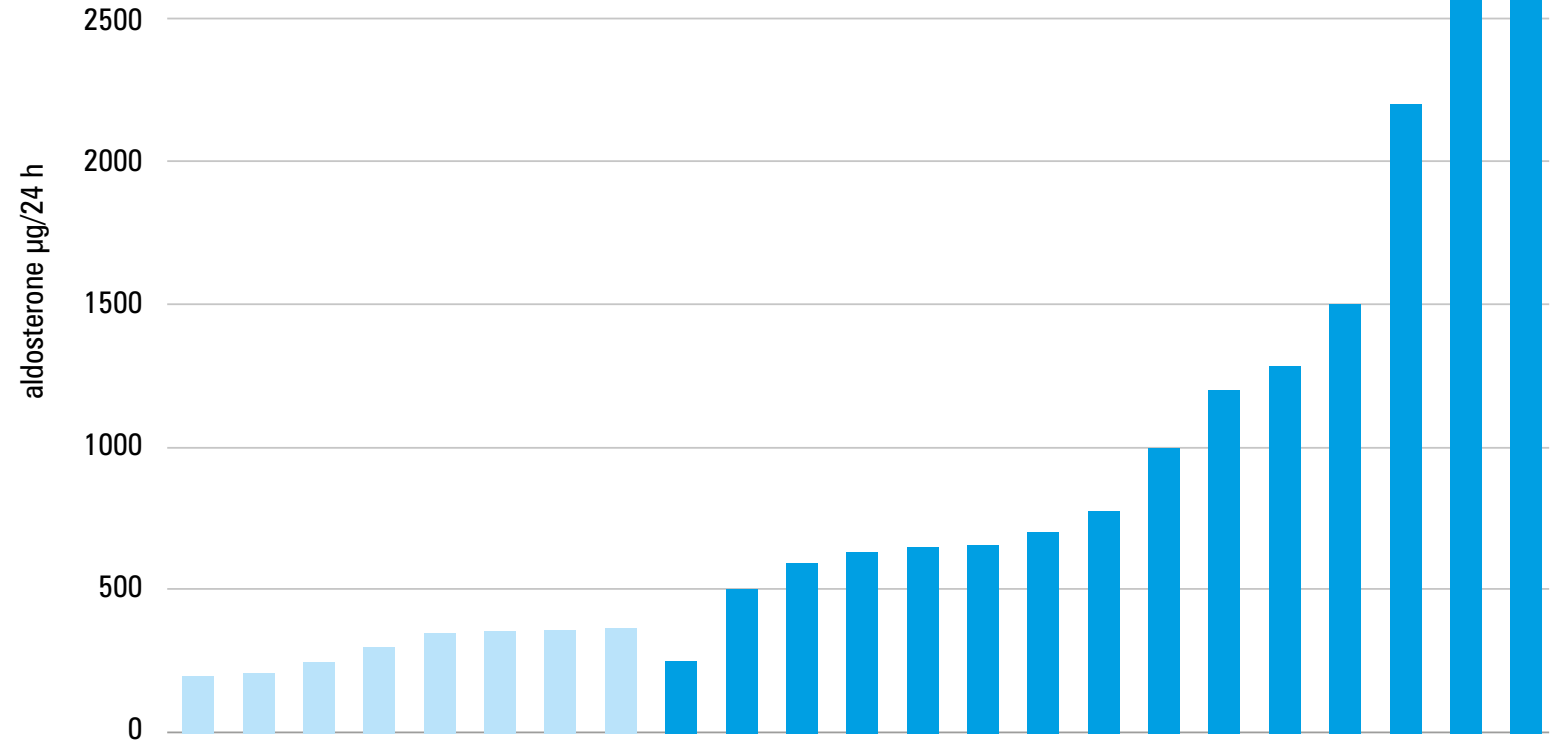

FIGURE 2 Urine aldosterone excretion in patients with essential hypertension and malignant hypertension. Adapted from Laragh et al. ${ }^{8}$ experimental hypertension and vascular pathology. In addition, our preliminary studies in humans have indicated that immune dysregulation is particularly evident in hypertension. ${ }^{22,23}$ Mice lacking T and B lymphocytes (Rag1-/-) were resistant to the development of severe hypertension in both angiotensin II and desoxycorticosterone acetate-salt-induced hypertension models, and this effect was greatly mediated by T-cell activation. ${ }^{22-24}$ Subsequent studies have indicated that a complex network of interactions between $\mathrm{T}$ cells, dendritic cells, monocytes, and B cells may be involved in hypertension. A mild form of hypertension develops in the absence of T cells, while severe hypertension is completely prevented. This could indicate a possible involvement of an inflammatory and immune mechanism, particularly in MHT. ${ }^{22-24}$

Activated memory and effector T lymphocytes responding to the prohypertensive factors are able to infiltrate the adventitia and perivascular fat, and possibly also the renal tissues or even the central nervous system. In the perivascular adipose tissue and in the kidney, these cells release proinflammatory cytokines such as interleukin (IL) 17, tumor necrosing factor $\alpha$ (TNF- $\alpha$ ), and interferon $\gamma$. Thus, the targeting of TNF- $\alpha$, IL-17, or chemotactic molecules such as the RANTES/CCR5 axis might be considered, and may become useful in the future management of resistant hypertension. ${ }^{22,25}$

Evidence of $\mathrm{T}$ cell-derived inflammation in hypertension is also slowly accumulating for humans. ${ }^{26}$ There is an increased fraction of immunosenescent, cytotoxic T cells in the circulation of patients with hypertension compared with normotensive subjects. Plasma TNF- $\alpha$ and IL-6 levels are correlated with BP, and a immunohistochemical analysis of biopsied renal tissue revealed a higher infiltration of $\mathrm{T}$ cells, both $\mathrm{CD}^{+}$and $\mathrm{CD} 8^{+}$, in patients with hypertensive nephrosclerosis, compared with normotensive controls. In patients with psoriasis treated with mycophenolate mofetil targeting $\mathrm{B}$ and $\mathrm{T}$ cells has shown to reduce BP. It is possible that immunomodulating agents will emerge in the future as a potential treatment option for patients with MHT, especially in the context of concomitant immune disorders. However, at present, there is no sufficient clinical evidence to support such an approach. ${ }^{26,27}$

Clinical features MHT may be accompanied by various symptoms and complications, the most characteristic being microangiopathic lesions or renal dysfunction (figure 3). Acute lesions in the retinal fundus may include arteriolar spasm, retinal edema, hemorrhages, exudates and papilledema, and engorged retinal veins. ${ }^{1}$

In $28 \%$ of patients with MHT, van den Born et $\mathrm{al}^{28}$ found thrombotic microangiopathy, characterized by thromboses of small vessels, intravascular hemolysis with fragmented red blood cells, elevated lactic dehydrogenase, and consumption of platelets. Less common clinical presentations may include fibrinoid necrosis within abdominal arteries producing major gastrointestinal tract infarction with an acute abdomen, necrotizing vasculitis as a feature of lupus, polyarteritis nodosa, or Takayasu arteritis. ${ }^{29-33}$

Urine may contain protein and red cells. In a few patients, acute oliguric renal failure may be the presenting manifestation, and various features of renal dysfunction (including proteinuria) may be present. Approximately half of patients with MHT have hypokalemia, reflecting 


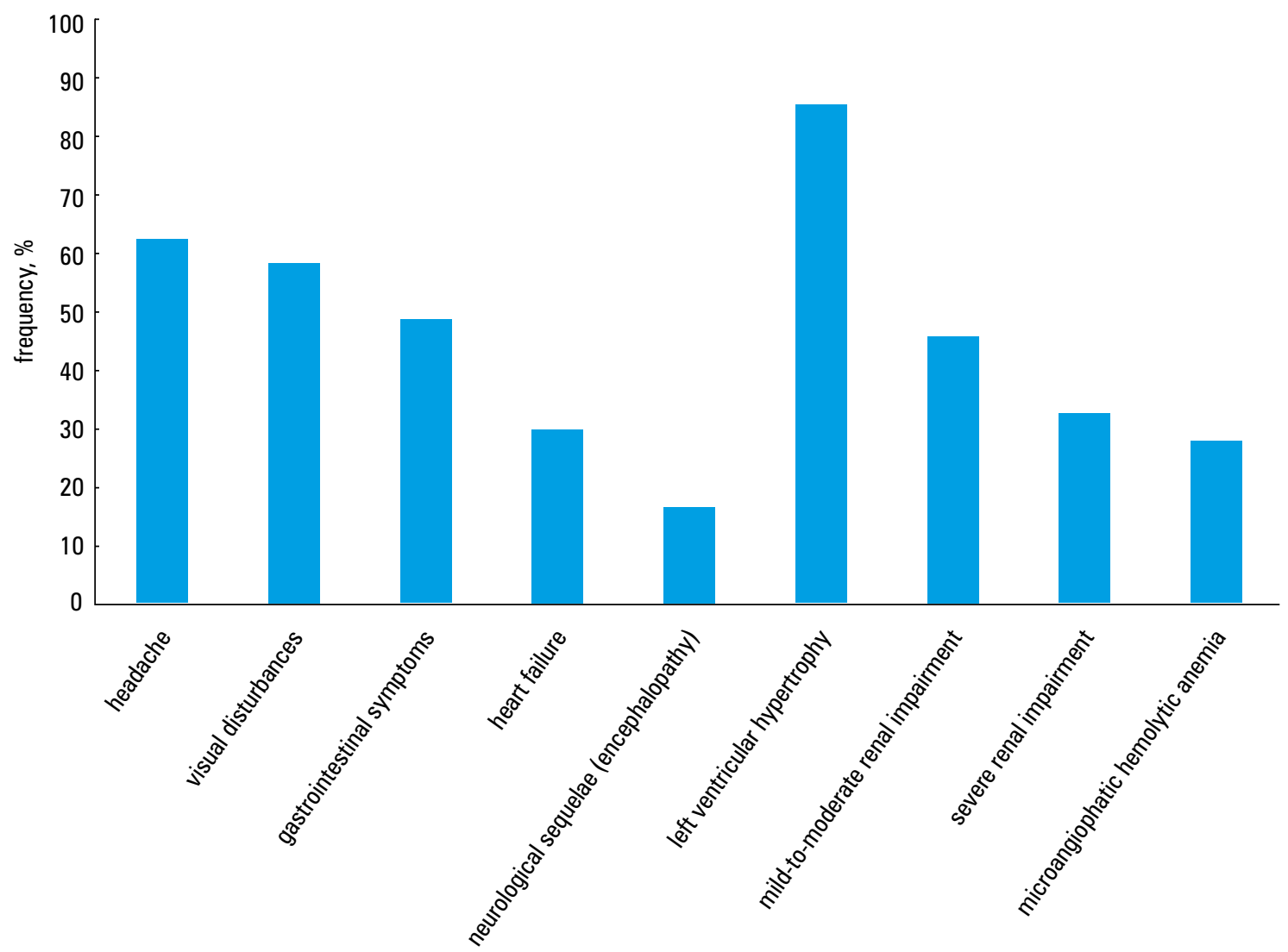

FIGURE 3 Presenting symptoms and associated complications in patients with hypertensive crisis and advanced retinopathy; gastrointestinal symptoms: nausea, vomiting, weight loss; mild-to-moderate renal impairment, serum creatinine concentration 115-300 $\mu \mathrm{mol} / \mathrm{l} ;$ severe renal impairment, serum creatinine concentration $>300 \mu \mathrm{mol} / \mathrm{l}$. Adapted from van den Born. secondary aldosteronism from increased renin secretion induced by intrarenal ischemia. Hyponatremia is common and may be severe. ${ }^{1}$

Multiple markers of inflammation, coagulation, platelet activation, and fibrinolysis were found in the blood of patients with various types of hypertensive emergencies, compared with the levels observed in normotensive controls. ${ }^{2,11}$

An electrocardiogram usually shows evidence of left ventricular hypertrophy (LVH). Echocardiography may show impaired systolic and diastolic function and delayed mitral valve opening. Regression of these abnormalities usually occurs after lowering of BP by antihypertensive therapy. ${ }^{1}$

Identifiable causes of malignant hypertension In patients with MHT, after an acute phase, an appropriate evaluation of identifiable causes of hypertension should be performed as quickly as possible. It is preferable to obtain the necessary blood and urine samples for required laboratory studies before instituting therapies that may markedly complicate subsequent evaluation. However, none of these procedures should delay effective therapy. MHT usually occurs in patients with long-standing preexisting hypertension and may be associated with a recent cessation of antihypertensive therapy. However, any form of secondary hypertension may progress to MHT. ${ }^{1-3}$

Renovascular hypertension is the most likely secondary cause, and, in a large series of patients with MHT, renal artery stenosis was the underlying cause of hypertension in $3.6 \%$ of the cases. It should in particular be sought in younger patients suspected of fibromuscular dysplasia, or in older patients with extensive atherosclerosis. Idiopathic IgA nephropathy has also been reported as a possible cause of MHT. . $^{134,35}$

Rarely, primary hyperaldosteronism may be associated with MHT, as documented by a small number of cases. A recent report described a 22-year-old patient with MHT, associated with primary hyperaldosteronism and LVH mimicking hypertrophic cardiomyopathy. ${ }^{35,36}$ Primary aldosteronism is typically defined by an increased plasma aldosterone level and suppressed plasma renin activity through a negative feedback mechanism. Hence, primary aldosteronism and MHT are at opposite ends of the renin spectrum, and their coexistence is thought to be very rare. ${ }^{36,37}$

There have also been sporadic reports of MHT in patients with pheochromocytoma and renin-secreting tumors. ${ }^{38-40}$

It is of note that, in most cases, MHT is accompanied by various life-threatening symptoms, signs, and associated complications. However, it is not uncommon to see patients denying any prior symptoms in the end stages of the hypertensive disease. In such cases, MHT is often unrecognized until a later stage in the progress of the disease, when clinical symptoms are becoming apparent and patients are symptomatic. ${ }^{1}$

Impact of malignant hypertension on the heart A few studies have confirmed that structural and functional cardiac abnormalities are present in patients with MHT, indicating features of cardiac damage and compensatory remodeling. However, 
these studies have had major limitations, such as a short follow-up duration and the lack of use of 3-dimensional echocardiography. ${ }^{41-43}$

$\mathrm{LVH}$, observed in patients with new-onset MHT, may at least partly reflect an adaptive response to persistently elevated BP, and its presence is associated with unfavorable prognosis. Indeed, the duration of the follow-up and the quality of BP control had a strong direct effect on prognosis in patients with MHT presenting with LVH. ${ }^{41-43}$

In contrast to previous observations based on a cohort of MHT patients with less rigorous $\mathrm{BP}$ control, the study by Shantsila et $\mathrm{al}^{41}$ showed that patients with adequately controlled MHT have a similar degree of LVH to that in control subjects without MHT. The study documented that all patients had preserved left ventricular ejection fraction, despite a median 12-year history of MHT, which did not differ from the values observed in the control group. In addition, the systolic and diastolic function indices were out of range, but did not differ between the MHT and non-MHT groups. ${ }^{41}$ These findings appear to be similar to the observations made by Gosse et $\mathrm{al},{ }^{42}$ who demonstrated a recovery of the left ventricular function with treatment during a short follow-up.

Taken together, the above observations prove that, despite good long-term BP control, patients with MHT have persistent structural and functional changes in the left ventricle on echocardiography, comparable to those observed in control non-MHT patients.

Long-term renal outcome Although the survival rate of patients with MHT has considerably improved with the introduction of antihypertensive therapy, MHT is frequently complicated by renal insufficiency, and ESRD still remains a significant cause of morbidity and mortality in this patient group. The STAT study ${ }^{44}$ demonstrated that, in patients hospitalized with acute severe hypertension, the presence of acute kidney injury was associated with a greater risk of serious outcomes, including mortality and additional end-organ damage. ${ }^{44}$

A retrospective analysis of 120 patients with MHT conducted in the Netherlands showed that patients with MHT had a markedly increased risk of ESRD after the acute phase. ${ }^{45}$ During a median follow-up period of 67 months, $31 \%$ of the patients reached the primary endpoint (ESRD), $15 \%$ reached the secondary endpoint (all-cause mortality), and $24 \%$ required kidney replacement. After the acute phase, initial serum creatinine levels and BP during follow-up were the main predictors of future ESRD.

In another retrospective study, Gonzalez et $\mathrm{al}^{46}$ reported on long-term renal outcomes in a cohort of 197 patients with MHT. Renal involvement was a major component of MHT, with $63 \%$ of the patients presenting with acute renal function impairment. The probability of renal survival in the entire cohort was $84 \%$ and $72 \%$ after 5 and 10 years of follow-up, respectively. The study confirmed that the severity of renal failure at presentation, worse BP control during follow--up, and severity of proteinuria were important prognostic factors for long-term renal outcomes. ${ }^{46}$

In another study, van den Born et $\mathrm{al}^{28}$ reported a relatively high prevalence of microangiopathic hemolysis in patients with MHT and showed that, in those subjects, microangiopathic hemolysis was an important indicator of both renal insufficiency and recovery.

It has been reported that, when intensive antihypertensive therapy was started in patients with MHT, renal function remained unchanged or improved in nearly half of those with initial renal insufficiency. In one series of 54 patients with MHT requiring dialysis, $22 \%$ of the subjects recovered sufficient renal function to allow withdrawal of dialysis. ${ }^{47,48}$

Considering that the activation of the renin-angiotensin-aldosterone system is an important pathogenic mechanism in MHT and that drugs affecting the system have specific antiproteinuric properties, a long-term treatment of patients with MHT should be based mainly on this type of agents.

Management MHT is a hypertensive emergency, and patients should receive immediate antihypertensive treatment owing to a high risk of renal failure, stroke, myocardial infarction, and heart failure.

Following the 2013 guidelines on hypertension from the European Society of Hypertension and European Society of Cardiology, the current treatment is based on agents that can be administered by intravenous infusion and titrated according to response, avoiding abrupt falls in BP and excessive hypotension. ${ }^{3}$

The goal of the immediate therapy should be to lower diastolic BP to approximately $110 \mathrm{mmHg}$. There is a consensus opinion to reduce MAP by no more than $25 \%$ during the acute phase in order to avoid cerebral hypoperfusion. Labetalol, sodium nitroprusside, nicardipine, nitrates, and furosemide are listed among the most frequently used intravenous drugs. However, due to the low incidence of MHT, there are no data to document which of these drugs is best, or whether their use is followed by a decrease in morbidity and mortality in this group of patients.

The study by Immink et $\mathrm{al}^{4}$ showed a significant difference in the decrease of systemic vascular resistance during the administration of sodium nitroprusside and labetalol (43\% and 13\%, respectively) in patients with MHT. These may be attributed to differential effects of these drug classes on systemic vascular resistance and heart rate in patients with MHT. ${ }^{49}$ It has also been recognized that antihypertensive drugs differ in their capacity to reduce central BP, whereas their effects on peripheral BP may be similar. ${ }^{4}$

Taken together, in the absence of definite evidence, clinicians must continue to administer 
FIGURE 4 5-year survival of patients with malignant hypertension by the year of diagnosis of malignant hypertension in a prospective registry of 446 patients with malignant hypertension attending the City Hospital in Birmingham, United Kingdom.

Adapted from Lane et al. ${ }^{5}$

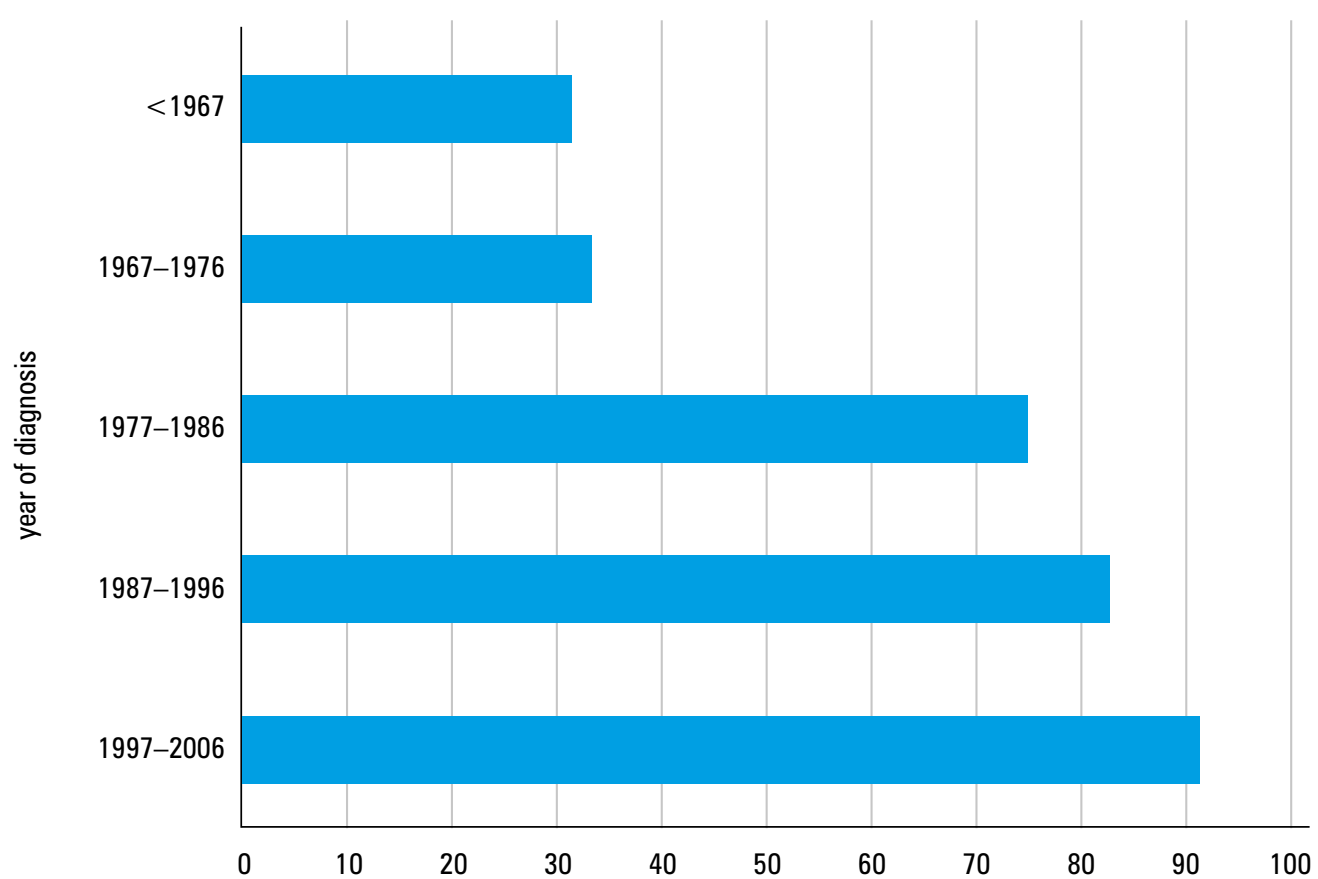

5-year survival, \%

parenteral drugs to markedly lower elevated BP in patients with a hypertensive emergency. However, this should be done carefully, under close supervision, and with the choice of drugs that allow for a gradual reduction in BP, that have no inherent toxicity, and that provide the ability to back down if the target organ function deteriorates. ${ }^{1-3}$

Prognosis If left untreated, the 1-year survival rate has been reported to be only $10 \%$ to $20 \%$, with most patients dying within 6 months. Effective treatment has led to a substantial improvement in the survival rate, with the rate at 5 years reaching between $60 \%$ and $75 \%$ in developed countries. However, in developing countries such as Nigeria, the prognosis appears to be considerably worse, with 1-year survival rates of only $37.5 \% .1,14,50-55$

The results from the largest prospective registry of 446 patients with MHT attending the City Hospital in Birmingham, United Kingdom, clearly showed a significant improvement in the 5-year survival rates, from $32 \%$ before 1977 to as much as $91 \%$ for patients diagnosed between 1997 and 2006 (FIgURE 4). ${ }^{5}$

The mortality rate was similar among white Europeans and African-Caribbeans, but significantly lower among South-Asians. The best independent predictors of overall survival were age, decade of MHT diagnosis, serum creatinine levels at presentation, and follow-up systolic BP. ${ }^{5}$

In addition, a retrospective cohort study that investigated national trends in the United States in hospital admissions for MHT showed a decrease in the mortality rate by $36 \%$ among patients diagnosed with MHT after 2007.?

The study by Amraoui et $\mathrm{a}^{50}$ documented that, despite a considerable improvement in the survival rate over the past decades, patients with a history of MHT remain at increased risk, and the annual incidence of all-cause mortality was higher in MHT patients compared with that in normotensive and hypertensive controls.

Taken together, despite satisfactory BP control with modern antihypertensive therapy, MHT continues to be an important clinical entity and may significantly contribute to an increase in total cardiovascular risk. 1,14,50-55

Summary In summary, MHT is not a "vanishing disease", having a relatively stable number of cases per year, but its prognosis and survival rates have significantly improved owing to earlier detection, tighter BP control, lower BP targets, better choice of antihypertensive drugs, and availability of hemodialysis and renal transplantation. However, despite the vast range of antihypertensive agents and effective BP control, MHT remains a significant clinical challenge.

Acknowledgments We would like to thank Mrs. L. Kozłowska and Mrs. M. Ciechanowska for their help during preparation of this manuscript. The research of TG and TM is funded by the $\mathrm{Na}$ tional Science Centre, Poland (NCN 2011/03/B/ NZ4/02454).

\section{REFERENCES}

1 van den Born BJ, Beutler JJ, Gaillard CA, et al. Dutch guideline for the management of hypertensive crisis - 2010 revision. Neth J Med. 2011; 69 : 248-255.

2 Kaplan NM, Victor RG. Kaplan's clinical hypertension. Wolters Kluwer, Philadelphia, 2015

3 Mancia G, Fagard R, Narkiewicz K, et al. 2013 ESH/ESC Guidelines for the management of arterial hypertension: the Task Force for the management of arterial hypertension of the European Society of Hypertension (ESH) and of the European Society of Cardiology (ESC). J Hypertens. 2013; 31 1281-1357 
4 van den Bogaard $B$, Immink RV, Westerhof $B E$, et al. Central versus peripheral blood pressure in malignant hypertension; effects of antihypertensive treatment. Am J Hypertens. 2013; 26: 574-579.

5 Lane DA, Lip GY, Beevers DG. Improving survival of malignant hypertension patients over 40 years. Am J Hypertens. 2009; 22: 1199-1204.

6 Scarpelli PT, Livi R, Caselli GM, et al. Accelerated (malignant) hypertension: a study of 121 cases between 1974 and 1996. J Nephrol. 1997; 10: 207-215.

7 Polgreen LA, Suneja M, Tang F, et al. Increasing trend in admissions for malignant hypertension and hypertensive encephalopathy in the United States. Hypertension. 2015; 65: 1002-1007.

8 Laragh JH, Ulick S, Januszewicz V, et al. Aldosterone secretion and primary and malignant hypertension. J Clin Invest. 1960; 39: 1091-1106.

9 Howard CG, Mitchell KD. Renal functional responses to selective intrarenal renin inhibition in Cyp1a1-Ren2 transgenic rats with ANG II-dependen malignant hypertension. Am J Physiol Renal Physiol. 2012; 302: F52-F59.

10 Hilme E, Hansson L, Sandberg L, et al. Abnormal immune function in malignant hypertension. J Hypertens. 1993; 11: 989-994.

11 van den Born BJ, Lowenberg EC, van der Hoeven NV, et al. Endothelia dysfunction, platelet activation, thrombogenesis and fibrinolysis in patients with hypertensive crisis. J Hypertens. 2011; 29: 922-927.

12 Shantsila A, Dwivedi G, Shantsila E, et al. Persistent macrovascular and microvascular dysfunction in patients with malignant hypertension. Hypertension. 2011; 57: 490-496

13 Shantsila A, Lane DA, Beevers DG, et al. Lack of impact of pulse pres sure on outcomes in patients with malignant phase hypertension: the West Birmingham Malignant Hypertension study. J Hypertens. 2012; 30: 974-979.

14 van den Born BJ, Koopmans RP, Groeneveld J0, et al. Ethnic disparities in the incidence, presentation and complications of malignant hypertension. J Hypertens. 2006; 24: 2299-2304.

15 Caro J, Morales E, Gutierrez E, et al. Malignant hypertension in patients treated with vascular endothelial growth factor inhibitors. J Clin Hypertens (Greenwich). 2013; 15: 215-216.

16 Cunningham MW, Jr., Sasser JM, West CA, et al. Renal nitric oxide synthase and antioxidant preservation in Cyp1a1-Ren-2 transgenic rats with inducible malignant hypertension. Am J Hypertens. 2013; 26: 1242-1249.

17 Efrati S, Berman S, Goldfinger N, et al. Enhanced angiotensin II production by renal mesangium is responsible for apoptosis/proliferation of endothelial and epithelial cells in a model of malignant hypertension. J Hypertens. 2007; 25: 1041-1052.

18 van den Born BJ, van Montfrans GA, Uitterlinden AG, et al. The M235 polymorphism in the angiotensinogen gene is associated with the risk of malignant hypertension in white patients. J Hypertens. 2007; 25: 2227-2233.

19 van den Born BJ, Koopmans RP, van Montfrans GA. The renin-angiotensin system in malignant hypertension revisited: plasma renin activity, $\mathrm{m}$ croangiopathic hemolysis, and renal failure in malignant hypertension. Am J Hypertens. 2007; 20: 900-906.

20 Milani $\mathrm{CJ}$, Kobori $\mathrm{H}$, Mullins $\mathrm{JJ}$, et al. Enhanced urinary angiotensinogen excretion in Cyp1a1-Ren2 transgenic rats with inducible ANG II-dependent malignant hypertension. Am J Med Sci. 2010; 340: 389-394.

21 Abrahamsen CT, Barone FC, Campbell WG, Jr, et al. The angiotensin type 1 receptor antagonist, eprosartan, attenuates the progression of renal disease in spontaneously hypertensive stroke-prone rats with accelerated hypertension. J Pharmacol Exp Ther. 2002; 301: 21-28.

22 Guzik TJ, Hoch NE, Brown KA, et al. Role of the T cell in the genesis of angiotensin II induced hypertension and vascular dysfunction. J Exp Med. 2007; 204: 2449-2460.

23 Crowley SD, Song YS, Lin EE, et al. Lymphocyte responses exacerbate angiotensin II-dependent hypertension. Am J Physiol Regul Integr Comp Physiol. 2010; 298: R1089-R1097.

24 Mattson DL, Lund $\mathrm{H}$, Guo $\mathrm{C}$, et al. Genetic mutation of recombination activating gene 1 in Dahl salt-sensitive rats attenuates hypertension and renal damage. Am J Physiol Regul Integr Comp Physiol. 2013; 304 R407-R414.

25 Muller DN, Shagdarsuren E, Park JK, et al. Immunosuppressive treatment protects against angiotensin II-induced renal damage. Am J Pathol. 2002; 161: 1679-1693.

26 Youn JC, Yu HT, Lim BJ, et al. Immunosenescent CD8+ T cells and C$\mathrm{X}$ - $\mathrm{C}$ chemokine receptor type 3 chemokines are increased in human hypertension. Hypertension. 2013; 62: 126-133.

27 Herrera J, Ferrebuz A, MacGregor EG, et al. Mycophenolate mofetil treatment improves hypertension in patients with psoriasis and rheumatoid arthritis. J Am Soc Nephrol. 2006; 17: S218-S225.

28 van den Born BJ, Honnebier UP, Koopmans RP, et al. Microangiopathic hemolysis and renal failure in malignant hypertension. Hypertension. 2005 45: 246-251.

29 Eguchi K, Kasahara K, Nagashima A, et al. Two cases of malignant hypertension with reversible diffuse leukoencephalopathy exhibiting a reversible nocturnal blood pressure "riser" pattern. Hypertens Res. 2002; 25: $467-473$
30 Deguchi I, Uchino A, Suzuki H, et al. Malignant hypertension with re versible brainstem hypertensive encephalopathy and thrombotic microangopathy. J Stroke Cerebrovasc Dis. 2012; 21: 915 e917-e920.

31 Akimoto $\mathrm{T}$, Muto $\mathrm{S}$, Ito $\mathrm{C}$, et al. Clinical features of malignant hypertension with thrombotic microangiopathy. Clin Exp Hypertens. 2011; 33: 77-83.

32 Nzerue C, Oluwole K, Adejorin D, et al. Malignant hypertension with thrombotic microangiopathy and persistent acute kidney injury (AKI). Clin Kidney J. 2014; 7: 586-589.

33 Khanal N, Dahal S, Upadhyay S, et al. Differentiating malignant hypertension-induced thrombotic microangiopathy from thrombotic thrombocytopenic purpura. Ther Adv Hematol. 2015; 6: 97-102.

34 Kumar $\mathrm{P}$, Arora $\mathrm{P}$, Kher $\mathrm{V}$, et al. Malignant hypertension in children in India. Nephrol Dial Transplant. 1996; 11: 1261-1266.

35 Zotos $\mathrm{P}$, Grivas D, Tsitsibis K, et al. Malignant hypertension associated with IgA nephropathy. Intern Med J. 2010; 40: 668-669.

36 Prejbisz A, Klisiewicz A, Januszewicz A, et al. 22-Year-old patient with malignant hypertension associated with primary aldosteronism. J Hum Hy pertens. 2013; 27: 138-140.

37 Kobayashi S, Hoshi A, Tanaka K, et al. Bilateral insular lesions related to malignant hypertension. Intern Med. 2012; 51: 1805-1806.

38 Kumar UM, Pande P, Savita S, et al. An Extra-adrenal Pheochromocytoma Presenting as Malignant Hypertension-A Report of two cases. J Clin Diagn Res. 2013; 7: 1177-1179.

39 Shera AH, Baba AA, Bakshi IH, et al. Recurrent malignant juxtaglomerular cell tumor: A rare cause of malignant hypertension in a child. $\mathrm{J}$ Indian Assoc Pediatr Surg. 2011; 16: 152-154

40 Prejbisz A, Antoniewicz AA, Kabat M, et al. Reninsecreting juxtaglomerular cell tumor of the kidney causing severe hypertension and polyuria Pol Arch Med Wewn. 2014; 124: 207-208.

41 Shantsila A, Dwivedi G, Shantsila E, et al. A comprehensive assess ment of cardiac structure and function in patients with treated malignan phase hypertension: the West Birmingham Malignant Hypertension project. Int J Cardiol. 2013; 167: 67-72.

42 Gosse $P$, Coulon $P$, Papaioannou $G$, et al. Impact of malignant arterial hypertension on the heart. J Hypertens. 2011; 29: 798-802

43 Nadar S, Beevers DG, Lip GY. Echocardiographic changes in patients with malignant phase hypertension: the West Birmingham Malignant Hypertension Register. J Hum Hypertens. 2005; 19: 69-75.

44 Szczech LA, Granger CB, Dasta JF, et al. Acute kidney injury and cardiovascular outcomes in acute severe hypertension. Circulation. 2010; 121 2183-2191.

45 Amraoui F, Bos S, Vogt L, et al. Long-term renal outcome in patients with malignant hypertension: a retrospective cohort study. BMC Nephrol. 2012; 13: 71.

46 Gonzalez R, Morales E, Segura J, et al. Long-term renal survival in malignant hypertension. Nephrol Dial Transplant. 2010; 25: 3266-3272.

47 James SH, Meyers AM, Milne FJ, et al. Partial recovery of renal function in black patients with apparent end-stage renal failure due to primary malignant hypertension. Nephron. 1995; 71: 29-34.

48 Lip GY, Beevers M, Beevers DG. Does renal function improve after diagnosis of malignant phase hypertension? J Hypertens. 1997; 15: 1309-1315.

49 Immink RV, van den Born BJ, van Montfrans GA, et al. Cerebral hemo dynamics during treatment with sodium nitroprusside versus labetalol in malignant hypertension. Hypertension. 2008; 52: 236-240.

50 Amraoui F, Van Der Hoeven NV, Van Valkengoed IG, et al. Mortality and cardiovascular risk in patients with a history of malignant hypertension: case-control study. J Clin Hypertens (Greenwich). 2014; 16: 122-126.

51 Lip GY, Beevers M, Beevers DG. Complications and survival of 315 patients with malignant-phase hypertension. J Hypertens. 1995; 13: 915-924.

52 Kadiri S, Olutade B0, Osobamiro 0. Factors influencing the development of malignant hypertension in Nigeria. J Hum Hypertens. 2000; 14 $171-174$

53 Ventura HO, Mehra MR, Messerli FH. Desperate diseases, desperate measures: tackling malignant hypertension in the 1950s. Am Heart J. 2001 142: 197-203.

54 Edmunds E, Beevers DG, Lip GY. What has happened to malignant hy pertension? A disease no longer vanishing. J Hum Hypertens. 2000; 14 $159-161$

55 Webster J, Petrie JC, Jeffers TA, et al. Accelerated hypertension-patterns of mortality and clinical factors affecting outcome in treated patients. Q J Med. 1993; 86: 485-493. 


\title{
Nadciśnienie tętnicze złośliwe - nowe aspekty starej jednostki klinicznej
}

\author{
Andrzej Januszewicz', Tomasz Guzik², Aleksander Prejbisz ${ }^{1}$, \\ Tomasz Mikołajczyk², Grzegorz Osmenda², Włodzimierz Januszewicz ${ }^{3}$ \\ 1 Klinika Nadciśnienia Tętniczego, Instytut Kardiologii, Warszawa \\ 2 Katedra Chorób Wewnętrznych i Medycyny Wsi, Uniwersytet Jagielloński, Collegium Medicum, Kraków \\ 3 Warszawa
}

\section{SŁOWA KLUCZOWE}

leczenie, nadciśnienie tętnicze złośliwe, patogeneza, występowanie

\section{STRESZCZENIE}

Nadciśnienie tętnicze złośliwe (malignant hypertension - MHT), nazywane także przyspieszonym nadciśnieniem tętniczym złośliwym lub fazą złośliwą nadciśnienia tętniczego, jest najcięższą postacią nadciśnienia tętniczego. Definiuje się je jako istotnie podwyższone wartości ciśnienia tętniczego z towarzyszącymi zmianami na dnie oka (płomykowate wybroczyny, wysięki, ogniska waty, z lub bez obrzęku tarczy nerwu wzrokowego). Pomimo dostępności licznych leków hipotensyjnych MHT pozostaje ważnym problem klinicznym. Częstość jego występowania jest bardzo niska, jednak bezwzględna liczba nowych przypadków nie zmieniła się na przestrzeni ostatnich dekad. Chociaż rola aktywacji układu renina-angiotensyna-aldosteron i dysfunkcji śródbłonka w patogenezie MHT została dobrze udokumentowana, wyniki ostatnich badań wskazują, że także układ odpornościowy może odgrywać istotną rolę w rozwoju tej choroby. Chorzy z MHT charakteryzują się nasilonymi powikłaniami narządowymi nadciśnienia tętniczego, w tym nieprawidłowościami strukturalnymi i funkcjonalnymi serca. Częstymi powikłaniami MHT są upośledzenie funkcji nerek oraz schyłkowa niewydolność nerek. Przeżycie chorych z MHT poprawiło się znacząco wraz ze zwiększeniem dostępności leczenia hipotensyjnego, niemniej jednak upośledzenie funkcji nerek i rozwój schyłkowej niewydolności nerek wciąż stanowią istotną przyczynę chorobowości i śmiertelności w tej grupie chorych. Podsumowując, MHT nie jest „znikającą chorobą", ponieważ charakteryzuje się stałą liczbą nowych przypadków rocznie. Rokowanie i przeżycie pacjentów z MHT poprawiło się natomiast znacząco w wyniku wcześniejszego rozpoznania, ściślejszej kontroli ciśnienia tętniczego, niższych wartości docelowych ciśnienia tętniczego, większego wyboru leków hipotensyjnych oraz zwiększenia dostępności leczenia nerkozastępczego i transplantacji nerek. 